\title{
A review of open-source ventilators for COVID-19
}

\section{Una revisión de los ventiladores de código abierto para el COVID-19}

\author{
ESQUEDA-ELIZONDO, José Jaime†*，JIMÉNEZ-BERISTÁIN，Laura，MIRANDA-PASCUAL， \\ María Elena and TRUJILLO-TOLEDO, Diego Armando \\ Universidad Autónoma de Baja California, Faculty of Chemical Sciences and Engineering, Mexico.
}

ID $1^{\text {st }}$ Author: José Jaime, Esqueda-Elizondo / ORC ID: 0000-0001-8710-8978, CVU CONACYT ID: 90966

ID $1^{\text {st }}$ Coauthor: Laura, Jiménez-Beristáin / ORC ID: 0000-0002-9362-5450, CVU CONACYT ID: 91007

ID $2^{\text {nd }}$ Coauthor: María Elena, Miranda-Pascual / ORC ID: 0000-0002-9469-3383, CVU CONACYT ID: 455846

ID $3^{\text {rd }}$ Coauthor: Diego Armando, Trujillo-Toledo / ORC ID: 0000-0003-1482-8581, CVU CONACYT ID: 232755

DOI: $10.35429 /$ JCA.2020.15.4.9.18

Received July 15, 2020; Accepted December 30, 2020

\begin{abstract}
In this paper, we present a review of the open-source mechanical ventilators developed worldwide during the beginning of the COVID 19 pandemic. There are many ventilators projects, some Ambu-based, below based and ones that use the air and oxygen lines of the hospital, by controlling the flow and pressure. First, we present the basics of mechanical ventilation concepts. Next, we present an overview of the principal open-source initiatives world, a description of the ventilator, and its working principles. Also, the webpages of each of the projects developed are shown. This paper intends to give the reader a start point of the mechanical ventilators proposed. Finally, we present a compilation developed by the international community where they present the main ventilator projects developed worldwide, where to get their information and the developers' experience. It is important to notice that most of them have not been approved yet by the medical authorities of their respective countries.
\end{abstract}

\begin{abstract}
Resumen
En este artículo se presenta una revisión de los ventiladores mecánicos de código abierto desarrollados en todo el mundo durante el comienzo de la pandemia de COVID 19. Hay muchos proyectos de ventiladores en el mundo, algunos basados en Ambu, turbinas y otros que usan las líneas de aire y oxígeno del hospital, controlando el flujo y la presión. Primero se presentan los conceptos básicos de ventilación mecánica. A continuación, se presenta una descripción general de las principales iniciativas de código abierto del mundo, una descripción breve del ventilador y sus principios de funcionamiento. También se muestran las páginas web de cada uno de los proyectos desarrollados. Este documento pretende dar al lector un punto de partida de los ventiladores mecánicos propuestos. Finalmente, se presenta una compilación desarrollada por la comunidad internacional donde enlistan los principales proyectos de ventiladores desarrollados en todo el mundo, donde obtener su información y la experiencia de los desarrolladores. Es importante notar que la mayoría de ellos aún no han sido aprobados por las autoridades médicas de sus respectivos países.
\end{abstract}

Ventilador, Código Abierto, COVID-19

Citation: ESQUEDA-ELIZONDO, José Jaime, JIMÉNEZ-BERISTÁIN, Laura, MIRANDA-PASCUAL, María Elena and TRUJILLO-TOLEDO, Diego Armando. A review of open-source ventilators for COVID-19. Journal Applied Computing. 2020. 4-15:9-18.

\footnotetext{
* Correspondence to the Author (Email: jjesqueda@uabc.edu.mx)

$\dagger$ Researcher contributing as first author.
} 


\section{Introduction}

On 11 March 2020, the disease is known as COVID-19, caused by a coronavirus, was declared a pandemic by the World Health Organization (WHO) (Asociación Colombiana de Medicina Crítica y Cuidado Intensivo, 2020; González-Castro et al., 2020; Servicio Murciano de Salud, 2020). As a result, many countries closed their borders and took steps to prevent the spread of the virus (Crowell, 2019).

Globally; China, Italy, the United States, Spain, and Germany are the countries with the highest number of confirmed cases, and are suffering a high demand for medical supplies (Worldometer, 2020).

In Mexico, 8772 confirmed cases and 712 deaths from COVID-19 (México, 2020) have been confirmed in Mexico until April 21 $1^{\text {st, }}$ 2020, as it is shown in Table 2. This table also shows how the number of cases has raised until August $16^{\text {th }}$ up to 517, 714 confirmed cases and 56,543 deaths.

\begin{tabular}{|l|r|r|r|r|}
\hline Date & \multicolumn{1}{l}{ Confirmed } & \multicolumn{1}{c|}{ Negative } & Suspicious & Deaths \\
\hline $4 / 21 / 20$ & 8,772 & 32,490 & 9,653 & 712 \\
\hline $8 / 16 / 20$ & 517,714 & 568,395 & 89,934 & 56,543 \\
\hline
\end{tabular}

Table 1 COVID-19 cases in Mexico until April 21 ${ }^{\text {st }}$ and until August $16^{\text {th, }} 2020$

Source: (México, 2020)

According to the number of cases reported in the aforementioned countries, the virus's expansion is exponential, at a rate that causes the collapse of health systems in a short time, according to the Ministry of Health (Secretaría de Salud, 2020), the most common symptoms of COVID-19 are fever, cough, sneezing, headache, general discomfort and in more severe cases there is difficulty breathing. Some patients may have pains, nasal congestion, rhinorrhea, sore throat, or diarrhea. These symptoms may be mild and appear gradually. Around $84 \%$ of the cases are recovered (Worldometer, 2020).

In contrast to the above, on average, $4 \%$ develop a serious and critical state (Worldometer, 2020). In these cases, where the most serious symptoms such as shortness of breath occur, techniques and equipment are used to assist the patient, such as mechanical fans.
So, the patients will require oxygen therapy coupled with mechanical ventilation to support adequate oxygen saturation $(>88 \%)$ in arterial (Andreoli, Benjamin, Grigss, \& Wing, 2015). The cost of a machine ranges from $\$ 12,500$ to 800,000 pesos each fan as reported in this year's financial year by the health sector (Gobierno de México, 2020). So, here we present a review of the open-source ventilators, developed worldwide to give a chance to people infected with Covid-19. There are two main kinds of PAVs proposed: pre-stage public access ventilator (PAV) and the ones based on artificial manual breathing unit (AMBU) bags with electric blowers to act as emergency ventilators (Pearce, 2020a).

\section{Mechanical Ventilators classification}

The mechanical ventilators can be classified on what factor terminates inspiratory flow: 1) pressure-cycled ventilators terminate flow when pre-set pressures are reached in airways; 2) volume-cycled ventilators provide a set volume of gas to the patient over a range of pressures, with a maximum pressure that had been set to avoid damage to the patient's lungs during delivery of the set tidal volume; 3 ) time-cycled ventilators set tidal volume by setting the inspiratory time and flow rate, and 4) flow cycled ventilators, where the inspiratory flow is terminated when the inspiratory flow rate drops below a specific level (Pearce, 2020b).

\section{Mechanical Ventilators parameters}

The most common commercial modes of mechanical ventilation both provide a specified number of breaths per minute (BPM) and are: 1) synchronized intermittent mandatory ventilation (SIMV) where patients can take additional breadths over the set rate and 2) assist control (AC) that uses triggering so that if the patient makes an effort to breathe, it helps them, and if not, it maintains the set rate. These modes can be used alone or in concert with 1) continuous positive airway pressure (CPAP), which uses a high-pressure reservoir and constant flow of gas that exceeds the patient's needs; 2) positive endexpiratory pressure (PEEP), which increases the residual reserve capacity and allows for many alveoli and small airways to remain open that would otherwise close off; or 3) pressure support ventilation (PSV), which adjusts the pressure on the fly as the patient breathes to maintain a preset inspiratory pressure.

ESQUEDA-ELIZONDO, José Jaime, JIMÉNEZBERISTÁIN, Laura, MIRANDA-PASCUAL, María Elena and TRUJILLO-TOLEDO, Diego Armando. A review of open-source ventilators for COVID-19. Journal Applied Computing. 2020 
For those designing open-source ventilators using any of those modes and methods, there is a good base of established literature to draw upon (Pearce, 2020b). Both kinds of ventilators were designed using lowcost technologies that were available.

\section{Open-source ventilators}

There are several commercial low-cost products like the Pumani bubble CPAP for infants, D-box, or One Breath Ventilators, which could be used to relieve some of the demand for conventional ventilators. In this paper, we do not try to make a market review of such devices, instead, we focus on the open-source ventilators.

\section{Open-source designs shared worldwide}

Since the pandemic has affected so many countries, an increase in these types of equipment developed at low cost has been developed these days (Crowell, 2019) (OxyGen Project, 2020).

These systems have already been developed since a couple of years ago, like the ones of (Crowell, 2019) (Williams, 2019), therefore it is considered to be a suitable design for these circumstances, thus ensuring that the function is correct. Likewise, these developments have been reviewed by teams from different countries and various disciplines such as mechanical, electrical, electronic, and medical engineers, testing against different realities. In short, these prototypes have already been successfully tested in different settings, so they were shared with the altruistic purpose of helping people in need.

\section{OxyGEN project, Spain}

It is a collaborative hardware project initiated and directed by Protofy.xyz, a Spanish company based in Barcelona, in charge of providing innovative hardware and software solutions. This project's mission is to provide a chance for survival to those who do not have access to a medical artificial ventilator for any reason. For this, they created an open, low-cost hardware system with simple and easily available components, based on the automation of a manual resuscitator (Ambu-bag), with the idea of contributing to saving lives (OxyGen Project, 2020).
It has received the approval of the AEMPS (Spanish Agency for Medicines and Health Products) to start its use on patients at all hospitals that adhere to the clinical study. Figure 1 shows the prototype of the OxyGEN project, notice that it is based on the compression of an Ambu bag using a cam system. The information and the project's webpage can be found at https://oxygen.protofy.xyz.
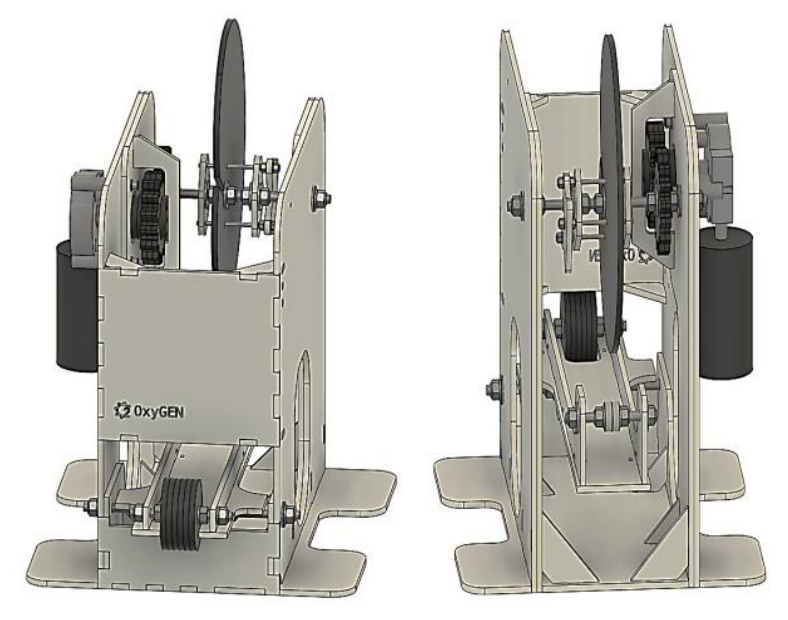

Figure 1 OxyGen project Source: (OxyGen Project, 2020).

\section{Open Source Ventilator (OSV), Ireland}

The Irish OSV company founded by Colin Keogh, Conall Laverty, and David Pollard, to build a team focused on Ireland developing a collaborative Field Emergency Ventilator (FEV) with the Irish Health Service ((OSCMS), 2020). To date, they have formed a team of engineers, designers, and medical professionals to develop new low-resource interventions, all working collaboratively online. Traditionally manufactured and bagged valve masks (BVMs), $3 \mathrm{D}$ printed components are being considered to maximize potential manufacturing capabilities. It is a fast-deploying, low-resource, open-source (in progress) fan design that uses a valve bagmask (BVM or Ambu-bag) as the core component. The block diagram of this project is shown in figure 2 and it can be noticed. The information of this project can be found at https://gitlab.com/open-sourceventilator/ventilator/OpenLung 


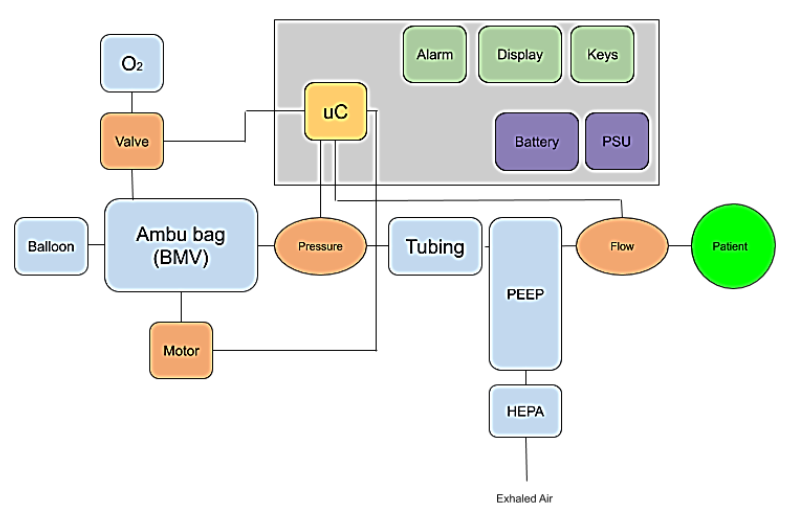

Figure 2 Diagram of the Open Source Ventilator from Ireland

Source: ((OSCMS), 2020).

\section{Project OpenAir, Portugal}

They work on medical devices to provide a simple and fast solution that can be reproduced and assembled anywhere in the world. This prototype implements the pressure-controlled continuous mandatory ventilation mode (PCCMV) with settable breathing rates, inspiration/expiration time ratios, and $\mathrm{FiO}_{2}$ modulation. Pure oxygen at the standard pressure of 4 bar $(400 \mathrm{kPa})$ is fed from the hospital supply to an adjustable pressure regulator with an output range of 20 to 40 mbar, allowing the PIP pressure to be set by just turning a knob. The regulator output is fed to the inspiration electro valve that should have enough aperture for the air to pass through easily at normal breathing flows (Pereira et al., 2020a). This prototype is shown in figure 3 . The details of this project can be found at https://projectopenair.org/en/home-2/.

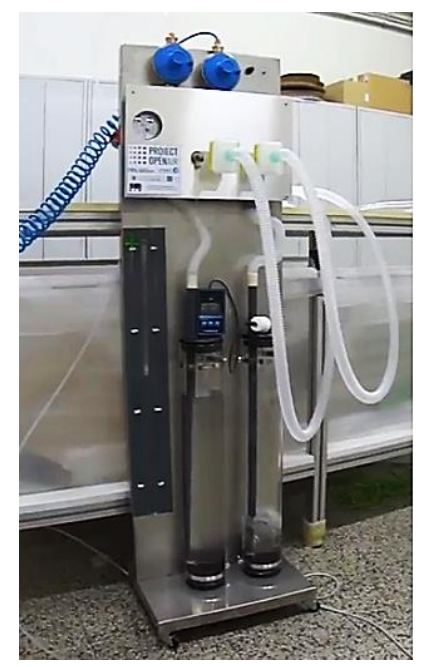

Figure 3 OpenAir final prototype

Source: (Pereira et al., 2020b)

\section{RespiraWorks, USA, Guatemala, Kyrgyzstan}

They are a team with backgrounds in medical devices, quality assurance, nuclear power, submarine life, and project management. They are located in Berkeley, Denver, Guatemala, Kyrgyzstan, and places around the world. They are working on an emergency ventilator, based on a blower and shown in figure 4 , to address the looming shortage in the developing world (RespiraWorks, 2020) and their webpage is https://respira.works/. Their cost is under USD 500 .

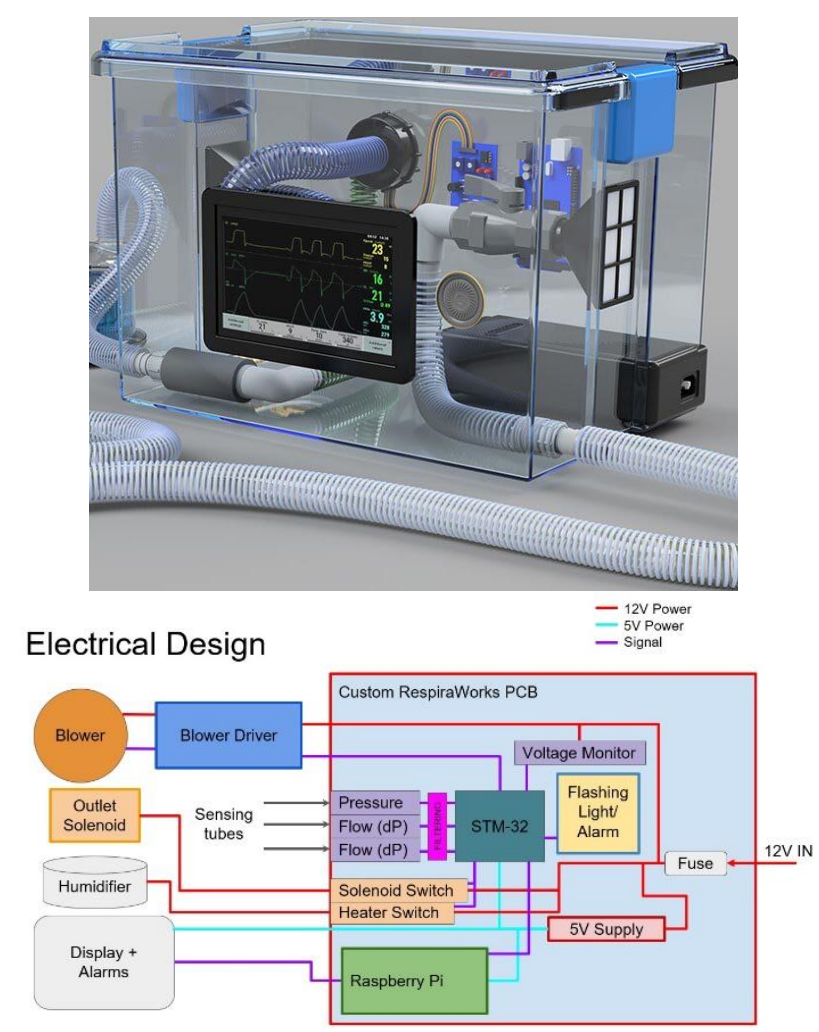

Figure 4 Respira Works project and the electrical diagram Source: (RespiraWorks, 2020)

\section{The Pandemic Ventilator Project, USA}

The Pandemic Ventilator Project is an opensource hardware project and the information presented of this project is only for development and investigative purposes. The prototypes presented are not fully functional devices and have had no safety testing done. This project consists of the bellows unit, which is made of wood, valves and piping, a PLC controller, some wires and switches, and a power supply unit. 
The whole unit is mounted on a piece of $1 / 2$ inch thick plywood that is 18 inches by 21 inches. a device agrees to waive any liability. The information on this project (Instructables, 2020) can be found at https://www.instructables.com/id/ThePandemic-Ventilator/. Figure 5 shows a diagram of this ventilator based on a bellow.

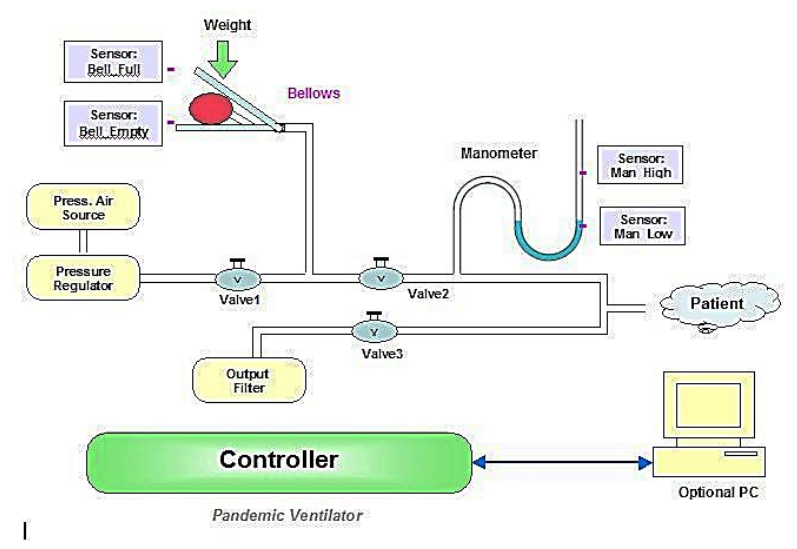

Figure 5 Pandemic Ventilator Source: (Instructables, 2020).

\section{MIT Emergency Ventilator (E-Vent) Project}

This project is based on automating a manual resuscitator, as a potential means for longer-term ventilation. This is a completely off-label use, but they recognize the global interest when a hospital has used up all ventilators and the only option is manual bagging a patient. This may allow less severe patients to be cared for by less specialized clinicians, while resources are focused on those most in need. It has a $12 \mathrm{~V}$ DC @ 5A power supply and is based on the open hardware platform Arduino UNO. Figure 6 shows the electrical system architecture of this project (MIT, 2020) and the information is available at https://e-vent.mit.edu/.

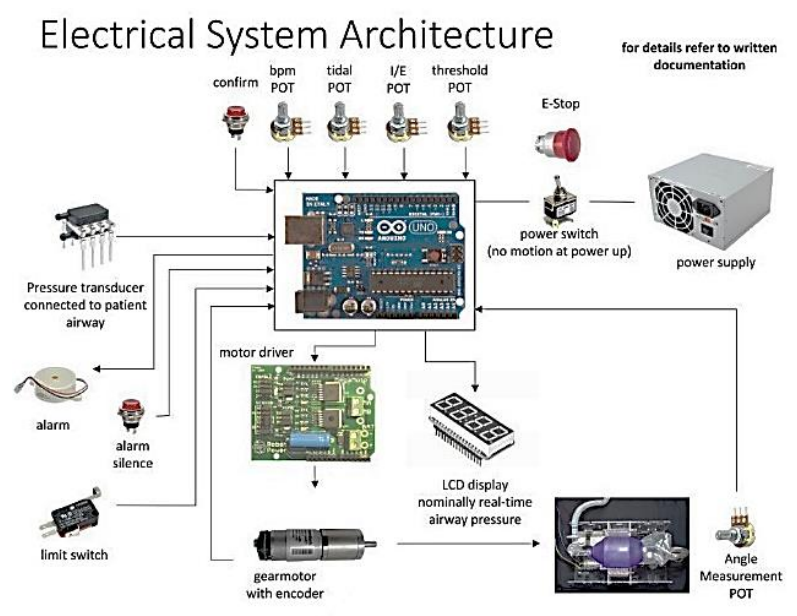

Figure 6 MIT E-Vent project diagram Source: (MIT, 2020)

\section{Open Source Ventilator Project, University of Florida}

It is a ventilator system for adults (older adults at higher risk) based on positive pressurevolume control for intubated patients who do not breathe spontaneously. The designs are modular, allowing different modules to be combined according to local availability. It has an out of box design: all parts are commercially accessible.

The design is inexpensive to build (parts for the base model are estimated to be under \$ 300 ) and assembles quickly (in less than TBD hours) with easily accessible parts (Florida, 2020). The information on this project can be found https://simulation.health.ufl.edu/technologydevelopment/open-source-ventilator-project/. Figure 7 shows the diagram of this project, and we can notice the pneumatics of this ventilator.

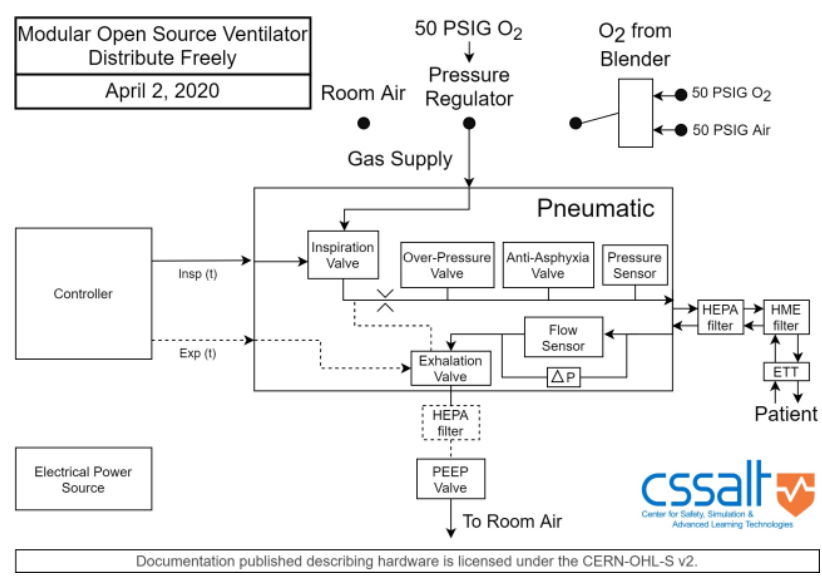

Figure 7 Open Source Ventilator Project diagram Source: (Florida University, 2020)

\section{Puritan Bennett 560 (PB 560), USA}

This device plans were released by Medtronic to help people in the COVID 19 pandemic. It is pump-based and it was designed in 2010 , so it has been a long time in use (Medtronic, 2020). This device is more complicated to build and also more expensive, but probably offers more features, and has already been approved by numerous governments. Another fact is that some of the elements are discontinued now and it is not easy to find them. Also, some industrial facilities are needed to build them. Figure 8 shows the Puritan Bennett 560 device. 


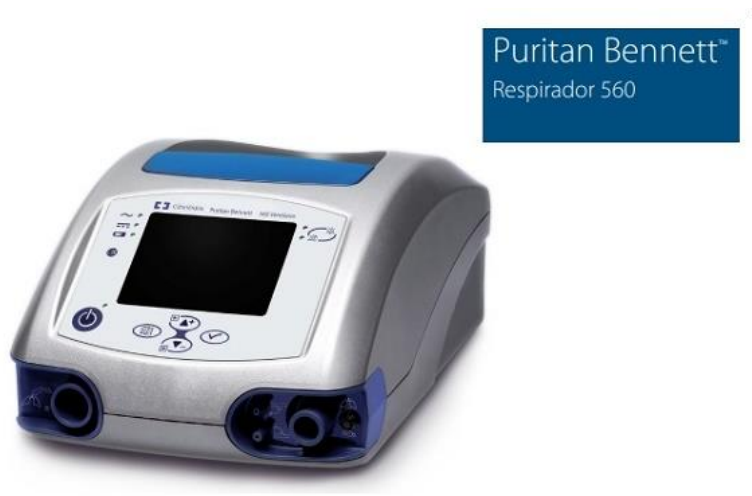

Figure 8 Puritan Bennett 560 ventilator Source: (Medtronic, 2020)

The information on this ventilator can be found at https://www.medtronic.com/usen/e/open-

files.html?cmpid=vanity_url_medtronic_com_o penventilator_Corp_US_Covid19_FY20, after filling a form.

\section{AmboVent, Israel}

"AmboVent" is a device inspired by the bagvalve-mask ventilators that paramedics use when they're manually ventilating patients in an ambulance, which also offers controls for respiration rate, volume, and maximum peak pressure. The device is being developed as a global partnership for the greater good, in opensource code mentality, on a non-profit basis to enable free and simple mass production by anyone, anywhere in the world. It is designed as an alternative automatic, controlled, ventilation system for adults, to be used only in emergencies when no other approved ventilation machines are available (Israel Air Force, 2020). Figure 9 shows the AmboVent project and all the information on this project can be found at https://members.smoove.io//view.ashx?message $=\mathrm{h} 44741568 \mathrm{O} 122392748 \mathrm{O} 219654 \mathrm{O} 122323322$ $\& \mathrm{r}=1009$.

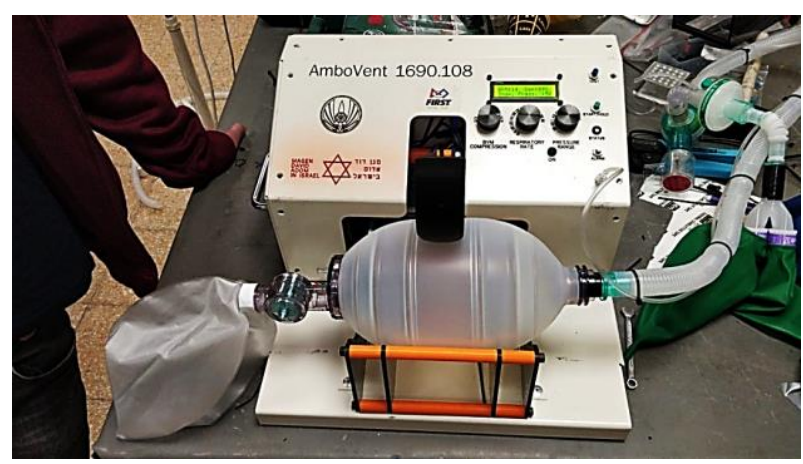

Figure 9 AmboVent project, final design Source: (Sloan, 2020).

\section{Other international efforts}

Also, at (Read, 2020) is published a classified Analysis of Open Source COVID-19 Pandemic Ventilator Projects, that can also be found at https://github.com/PubInv/covid19-vent-list, developed worldwide. This site has the goal to be helpful to those looking for quick information, and not to disparage any project. The ventilation projects are qualified from 0 or 1 to 5, in seven categories: Openness, Community Support, Buildability, Functionally Tested, Reliability Tested, COVID-19 Suitability, Clinician Friendly. Figure 10 shows the spreadsheet that contains the information of the analysis made of these ventilators' projects. The direct link to this spreadsheet is https://docs.google.com/spreadsheets/d/linYw5 H4RiL0AC_J9vPWzJxXCdlkMLPBRdPgEVK F8DZw/edit\#gid=0_(Read, 2020). Also, there is placed an email if there is a need to contact the developer's team. Next, these classification criteria are explained.

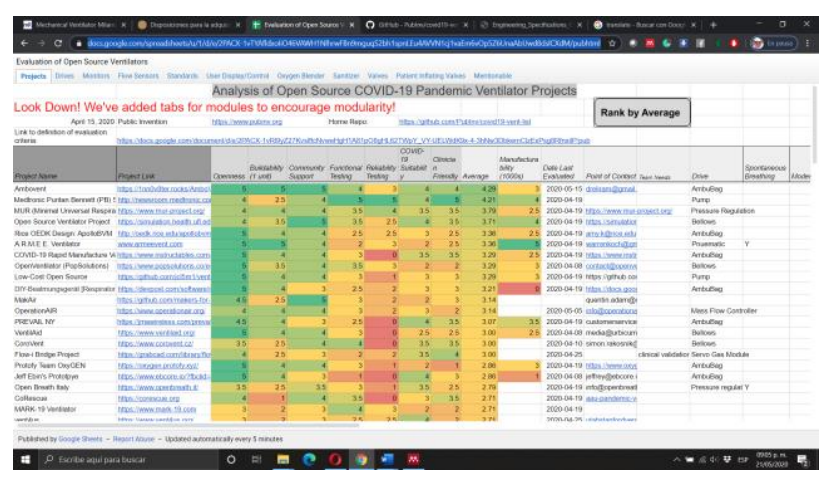

Figure 10 Analysis of Open Source COVID-19 Pandemic Ventilator Projects

Source: (Read, 2020).

The qualifications for these seven attributes are:

\section{Openness}

\section{- $\quad$ Not Open}

- Declared to be open, but no plans published

Have a repo with at least some plans?

Has a clear license strategy, regular updates to plans?

- Fully open, everything document, responsive community, clear license.

ESQUEDA-ELIZONDO, José Jaime, JIMÉNEZBERISTÁIN, Laura, MIRANDA-PASCUAL, María Elena and TRUJILLO-TOLEDO, Diego Armando. A review of open-source ventilators for COVID-19. Journal Applied Computing. 2020 


\section{Buildability}

Unbuildable.

Documents available but they require guesswork.

- $\quad$ All software and hardware transparent and documented. Some manufacturing instructions, such as a build video.

Complete documentations suggested reproducibility.

Has been successfully reproduced by another team purely from documentation.

\section{Community Support}

- Inactive; not point of contact.

- $\quad$ Point of contact, but unresponsive.

- Responsive leader or manager, more than one volunteer.

- $\quad$ Active community, weekly activity, and reports git-repo or other shared documents.

Large, active, open community.

\section{Functional Testing}

- $\quad$ In Design Phase, Not listed/tested.

- $\quad$ Makes a bag move.

- $\quad$ Tested with a test lung.

Tested for pressure and volume limits, with breath rate control.

Tested for alarms, multiple modes, $\mathrm{O}_{2}$ mixing.

- $\quad$ All test green (if asserted as a feature).

\section{Reliability Testing}

Not Listed.

Operates for one hour.

Operates for 12 hours.
Operates for 12 hours passing all functional test acceptably (low exception rate).

- $\quad$ Independent team operates for 48 hours passing all functional tests, data logs reviewed.

- $\quad$ Mean time between failure data starting to become meaningful.

\section{COVID-19 Suitability}

- $\quad$ In design phase/Not listed.

- $\quad$ Operates with supplemental oxygen.

- $\quad$ Pressure or volume control or both.

- PEEP.

- Sophisticated alarm capability and stabilizable of all patient contact points.

- $\quad$ Meets British RVMSv1 standards.

\section{Clinician Friendly}

- Unknown controls.

- No controls.

- $\quad$ Breath rate and volume control, standard ports.

- Breath rate, volume, and pressure control easy to set, standard ports, clear external labeling graphically and in the language of choice.

Alarms easy to set and understand, wholesale replication of an existing UI or conformance to a TBD UI standard.

- Data logging, informative, easy control, battery backup for moving. No training is needed in normal operation due to similarity with familiar designs. 


\section{Manufacturability (1000s)}

Note: This is usually zero until the Buildability of (1) unit (separate column) reaches 4.

Insufficient plans to duplicate a single unit.

- $\quad$ Bill of Materials (BOM) clear.

2d parts, 3d parts, code, all clearly documented.

- Electrical schematics and air circuit schematics clear. PCBs if any present and documented. Wiring if required fully documented.

- Basic instructions and special instructions present. Video instructions helpful. Documented in the language of choice, preferable more than one. Basic description of "smoke tests" and simple quality assurance present.

Either evidence of BOM availability in units of 1000 , or supply-chain flexibility of parts suggesting same. Documentation for handling supply-chain disruption present if minimal. Plans include manufacturing issues for non-expert workers. Detailed quality assurance plans present.

With this information, the people interested in building open source ventilators can have an idea of what project follow, according to their needs and the supplies available. More information about these criteria can be found at https://docs.google.com/document/d/e/2PACX1vR19yZ27KvslftcNvweHgH1 A81pO8gHL62T WpY_VY-UELWdK9x-4-

3hNw3DbkemClzExPsg8RfnxilP/pub (Read, 2020).

\section{Reviewed projects at the Analysis of Open Source COVID-19 Pandemic Ventilator Projects}

Table 2 shows some of the information presented at the Analysis of Open Source COVID-19 Pandemic Ventilator Projects, like the average obtained of all the projects presented in this paper and the same order.
In the first column, the Project's Name is presented. Next, the origin country where the project was developed is presented. The third column says if it is driven by Ambu bag, Positive Pressure Control, Fan, Bellow, or Pump. The fourth columns present the Buildability (Build) qualification obtained in the revision. Finally, the last column shows the average of all the parameters analyzed.

The Puritan Bennett 560 and the AmboVent had the top average of 4.45 but is important to notice that the Puritan Bennet has been developed by a medical company in 2010 , released for the pandemic and some of their core components are not easy to find. Also, the Puritan Bennet got a score of 2.5 in Buildability because of this condition. On the other hand, the AmboVent has been developed with more common components, and it has the same final average, but with a qualification of 5 in Buildability. In the second place, we have the Respira Works project, with an average of 3.25 and a Buildability qualification of 4 . In third place, we have the Open Source Ventilator of the University of Florida with an average of 3.15 and a Buildability score of 3.5. The OxyGEN, located in the fourth place, the project got an average of 2.95 with a Buildability qualification of 4. The E-Vent got an average of 2.80 and a Buildability qualification of 3 , so it was located in fifth place. All of these projects presented above got an average over the mean of 2.5. The Pandemic Ventilator got an average of 1.30, the Open Source Ventilator form Ireland got an average of 0.90 and the Open-Air project got an average of 0.70 .

\begin{tabular}{|l|l|l|r|r|}
\hline \multicolumn{1}{|c}{ Project } & \multicolumn{1}{c}{ Country } & \multicolumn{1}{c|}{ Drive } & Build & Average \\
\hline OxyGEN & Spain & Ambu bag & 4 & 2.95 \\
\hline OSV & Ireland & Ambu bag & 2 & 0.90 \\
\hline Open Air & Portugal & $\begin{array}{l}\text { Pressure } \\
\text { Control }\end{array}$ & 1 & 0.70 \\
\hline $\begin{array}{l}\text { Respira } \\
\text { Works }\end{array}$ & $\begin{array}{l}\text { USA- } \\
\text { Guatemala }\end{array}$ & Fan & 4 & 3.25 \\
\hline $\begin{array}{l}\text { Pandemic } \\
\text { Ventilator }\end{array}$ & USA & Bellow & 1 & 1.30 \\
\hline E-Vent & USA & Ambu bag & 3 & 2.80 \\
\hline $\begin{array}{l}\text { Open } \\
\begin{array}{l}\text { Source } \\
\text { Ventilator }\end{array}\end{array}$ & USA & $\begin{array}{l}\text { Positive } \\
\text { Pressure }\end{array}$ & 3.5 & 3.15 \\
\hline $\begin{array}{l}\text { Puritan } \\
\text { Bennett 560 }\end{array}$ & USA & Pump & 2.5 & 4.45 \\
\hline AmboVent & Israel & Ambu bag & 5 & 4.45 \\
\hline
\end{tabular}

Table 2 Comparison of the analyzed projects Source: Self-made 


\section{Conclusions}

There are a lot of different projects for designing and replicating ventilators for people in this COVID 19 pandemic. We can conclude that most of the projects developed worldwide are not approved yet for medical use, except for the OxyGen Project and the Medtronic's Puritan Bennett 560, but the buildability parameter is very important. The information collected and classified in the Analysis of Open Source COVID-19 Pandemic Ventilator Projects is very useful to know the international experiences obtained in the design and construction of these ventilators. Also, there are different kinds of ventilators, so anyone can choose the one who fits the needs of their local community.

\section{References}

(OSCMS), O. S. C.-19 M. S. (2020). Open Source Ventilator. Retrieved May 13, 2020, from https://opensourceventilator.ie/

Andreoli, T., Benjamin, I. J., Grigss, R. C., \& Wing, E. J. (2015). Cecil Essentials of MEDICINE. In Saunders, Elsevier (Vol. 6). https://doi.org/10.1017/CBO9781107415324.00 4

Crowell, R. (2019). Conoce el respirador manual automatizado que estamos creando en la UFG Revista Disruptiva. Retrieved April 20, 2020, from Investigación y Ciencia website: https://www.disruptiva.media/conoce-elrespirador-manual-automatizado-que-estamoscreando-en-la-ufg/

Florida, U. (2020). Open Source Ventilator Project » The Center for Safety, Simulation and Advanced Learning Technologies » UF Academic Health Center » University of Florida. Retrieved May 21, 2020, from https://simulation.health.ufl.edu/technologydevelopment/open-source-ventilator-project/

Force, I. A. (2020). Welcome to AmboVent 1690.108. Retrieved May 22, 2020, from https://members.smoove.io//view.ashx?message $=\mathrm{h} 44741568 \mathrm{O} 122392748 \mathrm{O} 219654 \mathrm{O} 122323322$ $\& \mathrm{r}=1009$
Gobierno de México. (2020). Instituto de Salud para el Bienestar | Instituto de Salud para el Bienestar | Gobierno | gob.mx. In Blog Instituto de Salud para el Bienestar. Retrieved from https://www.gob.mx/insabi/articulos/institutode-salud-para-el-bienestar-230778

Instructables. (2020). The Pandemic Ventilator: 6 Steps (with Pictures) - Instructables. Retrieved May 18, 2020, from https://www.instructables.com/id/The-

Pandemic-Ventilator/

Medtronic. (2020). Register to Download Ventilator Files | Medtronic. Retrieved May 22, 2020, from https://www.medtronic.com/usen/e/open-

files.html?cmpid=vanity_url_medtronic_com_o penventilator_Corp_US_Covid19_FY20

MIT, T. (2020). MIT E-VENT | Emergency ventilator design toolbox. Retrieved May 18, 2020, from https://e-vent.mit.edu/

OxyGen PRoject. (2020). OxyGEN Project. Retrieved April 20, 2020, from https://www.oxygen.protofy.xyz/

Pearce, J. M. (2020a). A review of open source ventilators for COVID-19 and future pandemics. F1000Research, $9,218$. https://doi.org/10.12688/f1000research.22942.1

Pearce, J. M. (2020b). A review of open source ventilators for COVID-19 and future pandemics. F1000Research, $9,218$. https://doi.org/10.12688/f1000research.22942.1

Pereira, A., Lopes, L., Fonte, P., Póvoa, P., Santos, T. G., Martinho, A., ... Pimenta, M. (2020). Prototype of an affordable pressurecontrolled emergency mechanical ventilator for COVID-19.

Read, R. L. (2020). Analysis of Open Source COVID-19 Pandemic Ventilator Projects. Retrieved May 23, 2020, from https://medium.com/@RobertLeeRead/analysis -of-open-source-covid-19-pandemic-ventilatorprojects-27acf9075f7e

RespiraWorks, T. (2020). Home । RespiraWorks. Retrieved May 14, 2020, from https://respira.works/ 
Secretaría de Salud, G. de M. (2020). COVID19 - gob.mx. Retrieved April 20, 2020, from https://coronavirus.gob.mx/covid-19/

Sloan, M. (2020). MDA and other Israeli organizations partner on making low-cost ventilator for coronavirus | AFMDA | Saving Lives in Israel. Retrieved May 22, 2020, from https://afmda.org/low-cost-ventilator-forcoronavirus/

Williams, M. (Rice U. (2019). Student invention gives patients the breath of life. Retrieved April 20, 2020, from Rice News website: http://news.rice.edu/2019/05/01/student-

invention-gives-patients-the-breath-of-life-2/

Worldometer. (2020). Coronavirus Cases. https://doi.org/10.1101/2020.01.23.20018549V 2 